\title{
MITIGATION MEASURE FOR VEHICLES EXHAUST EMISSION
}

\author{
Hikal, A. Z. S. ${ }^{(1)}$; Risk, M. W. L. ${ }^{(2)}$ and Shalaby, T. A. K. ${ }^{(3)}$ \\ 1) Faculty of Engineering, Ain Shams University 2) UNDP 3) Egyptian \\ Environmental Affairs Agency (EEAA)
}

\begin{abstract}
Motor vehicle emissions have shown to be of hazardous health influences. Its impact is amplified in urban areas such as the Greater Cairo Region (GCR). It is reported that the number of motor vehicles in Cairo is increasing at a rate of approximately 200,000 per year reaching 6,700,000 vehicles in year 2012, due to improving living style and the increase on economic growth; consequently, reducing motor vehicle emissions has become a major objective of environmental management activities in Egypt. In this context, Egypt's strategies include adoption of emission standards for new vehicles, enforcing emission standards for in-use vehicles, introducing proper low emissions techniques for gasoline and diesel powered engines, and encouraging cleaner alternative fuels, the main objective of the research is to illustrate the mitigation measure for the vehicles exhaust emissions.

Key Words: Green House Gases (GHG) -Million ton Carbon dioxide (CO2) equivalent (Mt CO2eq)-Vehicle-Fossil fuel-Greater Cairo region (GCR)Compressed natural gas (CNG)- Egyptian Environmental Affairs Agency (EEAA).
\end{abstract}

\section{INTRODUCTION}

The present rapid growth of car ownership with no available information on how much Greenhouse Gases (GHG) has released into the environment by vehicles powered by fossil fuels has been a concern to many stakeholders especially with no study of how to reduce those GHG emissions. The negative impact of the increase of the GHG emissions flow is an increase in 
the temperature and causes what is internationally known as the "Global Warming".

The expected shortage of fossil fuels in the future with the rapid growth of fuel consumption makes the planning of transport sector opportunities for GHG mitigation options are very important. Transport planning cannot be done without clear and complete data and information about the fossil fuels consumed or used.

The Government of Egypt (GOE) made some efforts for reduction of traffic pollutants in Greater Cairo Area (GCA) such as establishing the strategic plan for improving air quality that includes several measures aiming at the reduction of air pollution through regulating exhaust emissions;

The transport sector contributes $28 \%$ of the total final consumption of energy in Egypt in 2009. Oil consumed in the transport sector accounted for around $29 \%$ of the total oil consumption in $2008 / 2009$. The transport sector consumed around 300 Tera-Joule (TJ) of diesel and 220 TJ of gasoline. Gas still plays within transport a minor role. The majority of fossil fuel energy consumption in the transportation sector is from petroleum- based fuels (97\%), with a small amount from natural gas (3\%);

The cost of energy products in Egypt is impacted by social and political factors more than the economic costs of these products. The consumer prices of these products are much less than their comparable international prices as well as their production and supplying cost. The government has already abolished a big portion of the subsidies on 92 and 95 octane gasoline types and its price has increased from EGP 2.60, 2.75 per liter to EGP 3.50, 5.85 
per liter, prospectively. The aim is to reduce the general budget deficit. However, Egypt continues to have the lowest fuel prices for diesel and gasoline compared to other third world countries.

Egypt`s GHG emissions* showing the fastest growing GHG emissions with an increase of around $65 \%$ in the last 20 years. Total GHG emissions in Egypt increased from 193 Million ton CO2 equivalent (Mt CO2eq) in the year 2000 to $318 \mathrm{Mt}$ CO2eq in the year 2010, CO2 emissions represent around 2/3rd of total GHG emissions in Egypt, Considering only $\mathrm{CO} 2$ emissions from fossil fuels these increased by $127 \%$ between 1990 and 2010 reaching $178 \mathrm{MtCO} 2$ in 2010.

The development of $\mathrm{CO} 2$ emissions from fossil fuels are shown in Figure1. *( National Communications Reports)

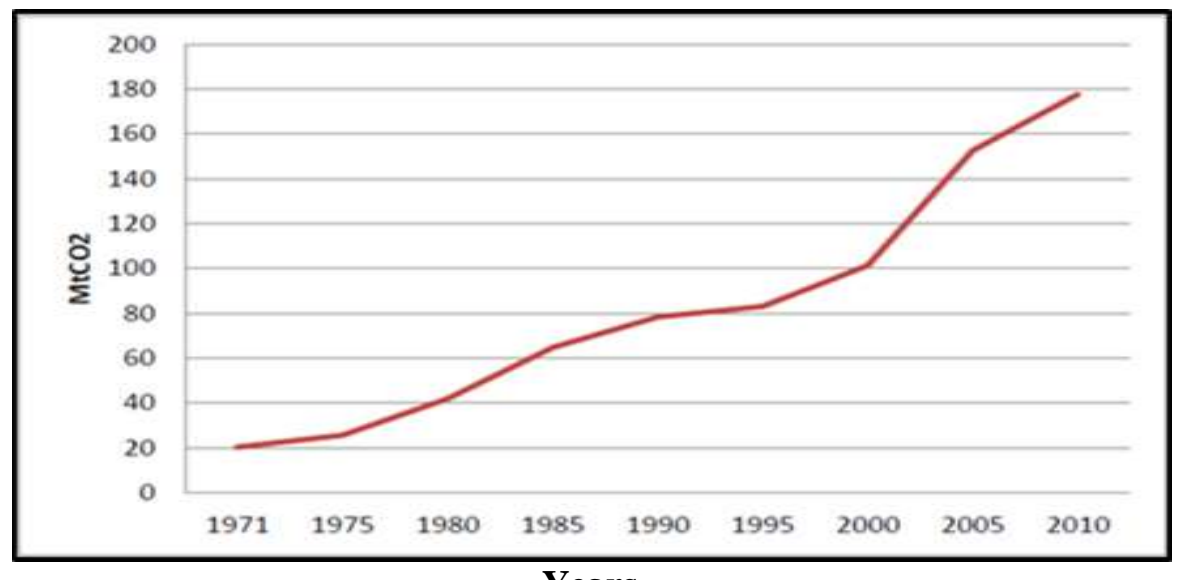

Years

Figure (1): CO2 Emissions from Fossil Fuels in Egypt

Source: EIA, 2013 
Transport modes based on fossil fuels emitting around $38.4 \mathrm{MtCO} 2$ representing * around $22 \%$ of year 2010 emissions, while the road transport is responsible for $35.4 \mathrm{MtCO} 2$ or around $92 \%$ of all transport related emissions. Transport related emissions per capita where thus around $0.5 \mathrm{MtCO} 2$ per annum in Egypt which is around 50\% of the world-wide average.

Total GHG emissions (includes $\mathrm{CH} 4$ and $\mathrm{N} 2 \mathrm{O}$ emissions) from the transport sector were in 2010 around 45.2 MtCO2eq. Figure 2 shows evolution of GHG emissions in the transport sector. The average annual growth rate over the last 10 years has been $5.1 \%$. Greater Cairo Region (GCR) contribute around $40 \%$ of the total Egyptian transport emissions amounted by 18 MtCO2eq of GHG emissions in year 2010.*(Third National Communication Report-TNC)

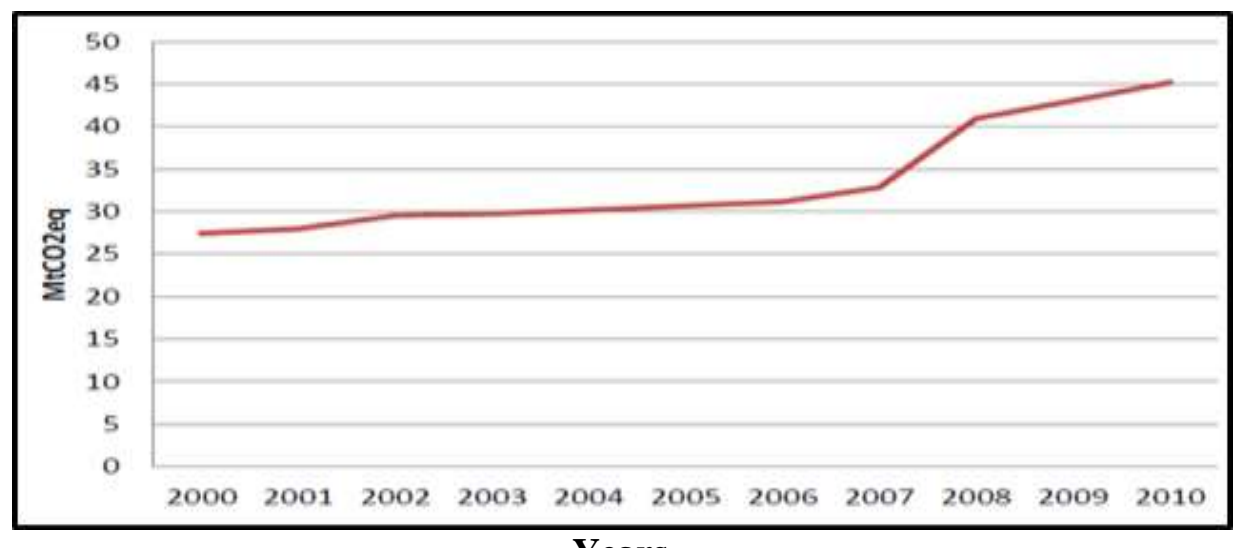

Years

Figure (2): Transport GHG Emissions in Egypt

Source: EEAA 


\section{METHODOLOGY FOR ESTIMATING GHG}

There are two approaches for calculating the emission factor. The first one is "The Energy based approach" which is the simplest and accurate way of calculating emission factors. It is used to record energy use and relate measured $\mathrm{CO} 2$ to energy values; it is clearly preferable where total fuel is known from fuel records. The division of fuel among different vehicle categories can be calculated from meter reading and known fuel economy for each category. The general equation takes the following form:

tyv $=\frac{n y v}{N}$

\section{Where:}

$\mathrm{y}=$ model year vehicles type subgroup

$\mathrm{v}=$ vehicle type subgroup

$\mathrm{t}=$ fraction of travel of subgroup

$\mathrm{n}=$ number of measurements of subgroup

$\mathrm{N}=$ total number of measurements

The second approach* is "Activity based approach" which it is possible to estimate the carbon dioxide inventory of a transport operation by using activity based emission factor and apply in a simple formula in the absence of fuel break down data. Average emissions of vehicles are different in different operating modes based upon vehicle's speed and acceleration, driving can be divided into four modes:(1) Acceleration; (2) Cruise; (3) Deceleration; and (4) Idle.*(United Nation Framework Convention for Climate ChangeUNFCCC) 
J. Environ. Sci.

Institute of Environmental Studies and Research - Ain Shams University

The general equation of this method takes the following form:

$$
\mathrm{mCO} 2=\sum_{1}^{n} \mathrm{EFi}_{\mathrm{i}} * \mathrm{Di}
$$

where:

$\mathrm{mCO} 2=$ Annual $\mathrm{CO} 2$ Emissions from vehicles, $\mathrm{kg}$

$\mathrm{EFi}=$ Activity base emission factor of vehicle category $\mathrm{i}, \mathrm{kg} / \mathrm{km}$

$\mathrm{Di}=$ Total distance travelled by vehicle category $\mathrm{L}, \mathrm{km}$

The Methodologies for estimating greenhouse gas (GHG) emissions by sector for the different gases $(\mathrm{CO} 2, \mathrm{CH} 4, \mathrm{~N} 2 \mathrm{O})$ for the Road transportation sector in Greater Cairo presenting that the Intergovernmental Panel for Climate Change (IPCC - 1996), and IPCC good practice guidance-2000 guidelines were used for estimating the greenhouse gases, insuring that Inventory sartorial tables and IPCC worksheets, and the Default emission factors were used in preparing the inventory, uncertainty analysis was provided.

The projected GHG Emissions in the Transport Sector are based on the GHG emission growth in the transport sector of the last decade (5.1\%). The projected GHG emissions of the transport sector in GCR would be around 30 MtCO2eq for the year 2020 as shown in figure (3). The annual increase is based, as on the increase in the number of trips, a slight increase in the average trip distance due to spatial city growth, an increased in private motorization rate, and drops in the average occupation rate observable in most countries in private means of transit as well as in public transit due to increased comfort demands. No significant change in the specific fuel 
consumption of vehicles is expected as the technological improvement through fleet renovation is contrasted with:

- A lower average speed with more stop-and-go traffic resulting in increased emissions as well as, basically for buses, the increased usage of more comfortable $\mathrm{A} / \mathrm{C}$ bus

- Units with higher fuel consumption basically in summer months.

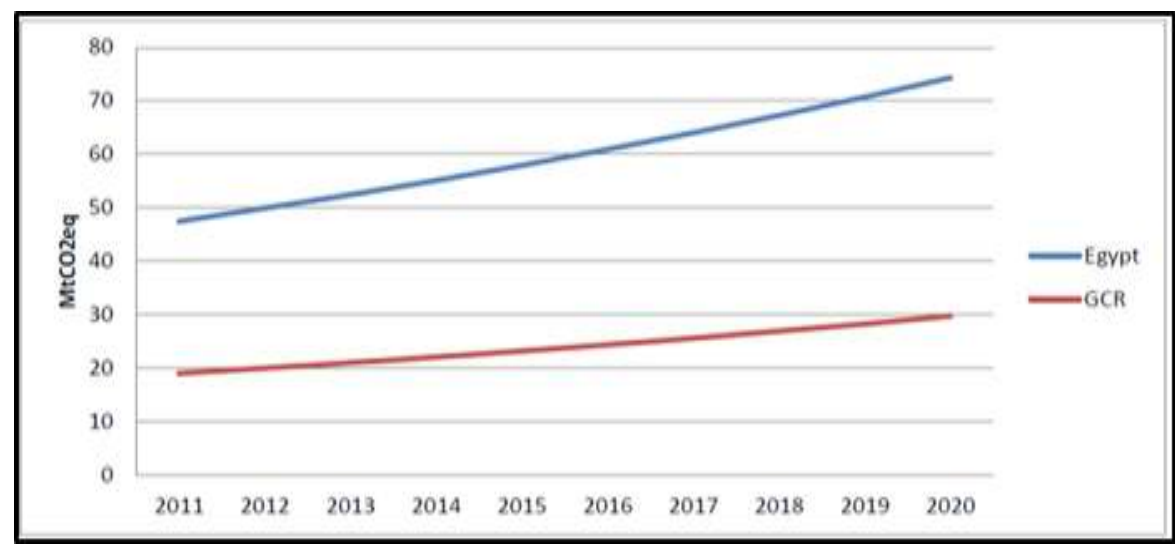

Years

Figure (3): Projected GHG Transport Emissions until 2020 (MtCO2eq)

Source: EEAA

Today locally manufactured and imported vehicles are not subject to any emissions standards that would guarantee their compliance with international emissions regulations applied in the developed countries, The Ministry of Environment (MOE) and the Egyptian Environmental Affairs Agency (EEAA) identified entities vested in the authority of taking the needed institutional decisions and undertaking the needed executive procedures that will ensure compliance of new vehicles with the necessary environmental regulations. These entities include the Ministries of Environment, Interior, Petroleum, Industry and Mineral Resources, and Trade and Supply. In 
addition to the Federation of Egyptian Industries (representing the local manufacturers), and the Federation of Egyptian Chambers of Commerce (representing local importers).

In order to establish a system for enforcing emission limits, the Government of Egypt (GOE) implementing the Air Improvement system include component namely, implementation of a vehicle emission testing program (VET). VET Program aims to:

- Achieve vehicle emissions reduction and improved vehicle fuel efficiency by designed a system in place to test emissions of vehicles applying for registration renewal/issuance,

- Improve fuel efficiency by $10 \%$ and reduce emissions through increasing capabilities for gasoline-powered passenger cars and diesel- powered public transport buses.

An On-Road Testing (ORT) Program within the framework of the Memorandum of Understanding (MOU) signed by the Egyptian Environmental Affairs Agency (EEAA) and the Minister of Interior (Traffic Authority), the Air Improvement Program implemented an ORT Program for vehicles. The objective of the ORT program is to collect emissions data and create public awareness for upcoming VET requirements.

Types of tested vehicles are the gasoline and diesel powered vehicles registered in the Greater Cairo area (Cairo, Giza and portions of Qalubiya). Two hundred sixty thousand $(260,000)$ vehicles have been tested during 2006-2013. The test procedures measured HC and CO concentrations at idle for gasoline powered vehicles. Diesel vehicles were tested for exhaust opacity 
during unloaded engine free acceleration. The compliance rate with the existing emissions standards is in the order of 63\%, as shown in Figure 4.

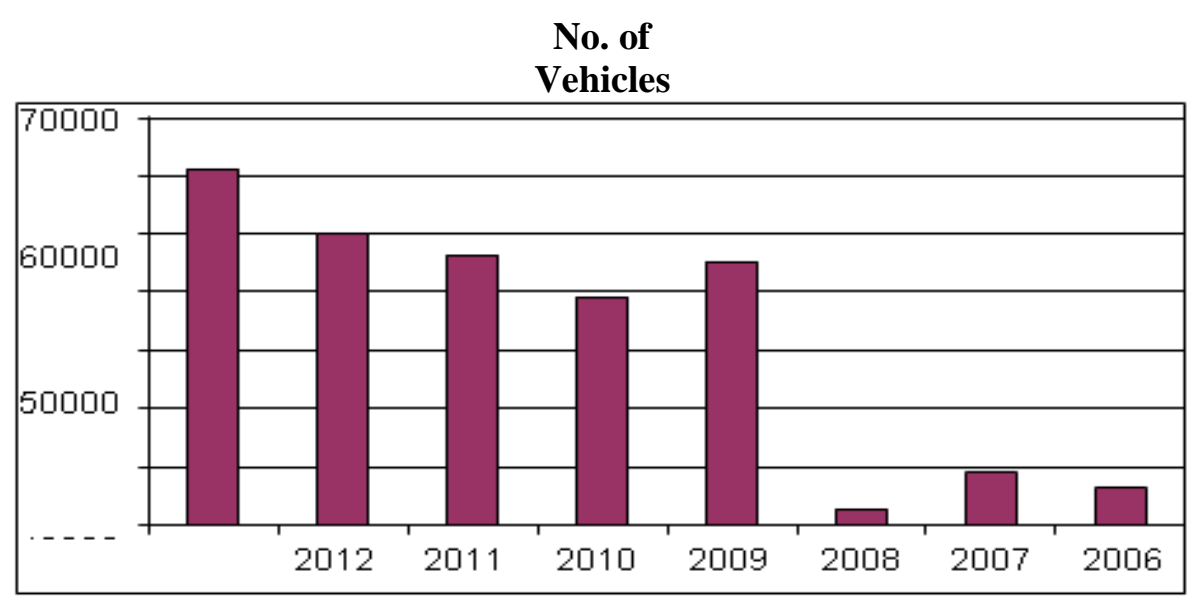

Years

Figure (4): Tested Vehicles during 2006-2013

Source: Vehicle emission technical center EEAA

The emission standards for $\mathrm{HC}, \mathrm{CO}$ and particulate/visible smoke will be based upon the statutory requirements of Law 4 of 1994. (See table 1 ) An appropriate Ministerial decree will be required to specify the test measurements for all vehicles to be included in the program, the testing mechanism and the applicable fines for non- compliance

Table (1): Egypt legislative in Environmental law no. 4/1994 EEAA

\begin{tabular}{|c|c|c|c|}
\hline Model year & $\mathbf{2 0 0 3}$ & $\mathbf{2 0 0 3 - 2 0 0 9}$ & 2009> \\
\hline \hline CO & $\% 4$ & $\% 1.5$ & $\% 1.2$ \\
\hline HC & $600 \mathrm{ppm}$ & $300 \mathrm{ppm}$ & $200 \mathrm{ppm}$ \\
\hline Opacity & $30 \%$ & \multicolumn{2}{|c|}{$25 \%$} \\
\hline
\end{tabular}


J. Environ. Sci.

Institute of Environmental Studies and Research - Ain Shams University

\section{RESULTS}

The preliminary analysis of the data of the vehicles having non-visible smoke indicates that the overall compliance of this category with emissions limits is in the order of $63 \%$. Failure rates due to violation of $\mathrm{CO}$ and $\mathrm{HC}$ are in the order of $26 \%$ and $21 \%$ as calculated, respectively. The category of failing vehicle includes cheap popular vehicles makes, as well as expensive ones.

In conclusion, test results confirmed the need for an effective low emission to replace the common performance tune-up. In addition, EEAA is working to develop the capacity of the local vehicle repair industry through placement of similar analyzers in service stations and training of technicians employed there.

\section{RESULTS ANALYSIS}

The negative effects of burning diesel fuel to the ecological system and to health are well known and documented. Nevertheless, diesel fuel consumption increased from 5.6 million tons in 2003 and reaches 8.3 million tons by the year 2011-2012. Thus using of alternative fuels such as Compressed Natural gas (CNG) is both available and environmentally friendly. They are considered one of the mitigation measures in the transport sector, especially $\mathrm{CNG}$ vehicles are running on an internal combustion engine (ICE). The abatement potential from these types of vehicles originates from the lower $\mathrm{CO} 2$ equivalent intensity of natural gas compared to gasoline and diesel; this makes CNG the logical alternative fuel for diesel, especially for the transport sector. 
CNG has already proven itself as a successful substitute for gasoline in the transportation sector in Egypt. The number of privately owned taxicabs that have converted from gasoline to $\mathrm{CNG}$ has exceeded all expectations. As shown in Figure (5) the Ministry of Petroleum is currently struggling to keep up with the tremendous demand for conversion to CNG.

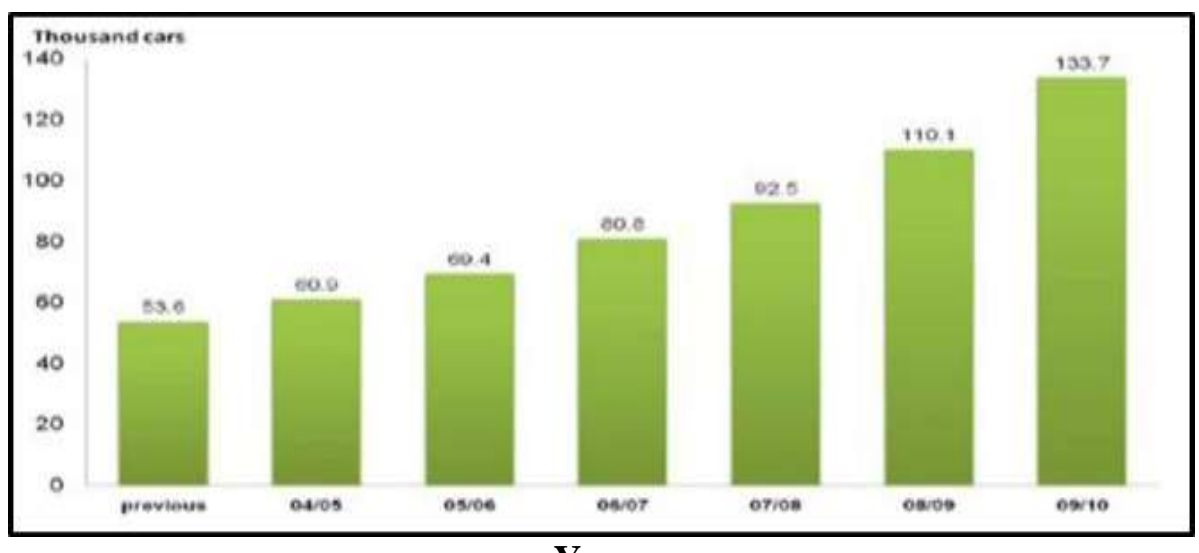

Figure (6): CNG Vehicles in Egypt

Source: Ministry of Petroleum

\section{CONCLUSION}

The success of a VET program is highly dependent upon obtaining consensus from EEAA, Governorates and Traffic Departments regarding their roles and responsibilities as well as the approach to design, and implementation of the program. The successful mitigation measures for mobile sources of emissions require collaboration of the efforts of the government and the public. More specifically Governorates, investors and motorists who are the main stakeholders in achieving a successful program that contributes to sustainable development. 


\section{REFRENCES}

Abouleinein, S.,El-Laithy, H., and Kheir-El-Din, H.,(2009): The Impact of Phasing Out Subsidies of Petroleum Energy Products In Egypt Study, Egyptian Center for Economic Studies ECES Working Paper No. 145. www.eces.org.eg

Ali S. Huzayyin, and Hindawy Salem, (2009): DRTPC Study Experts, Past and present trends of urban transport and related energy consumption, greenhouse gas and pollutants emissions in Greater Cairo Study, world conference on transport research publication, www.wctrs-society.com, Lisbon.

Ali S. Huzayyin, and Hindawy Salem, (2013): Analysis of thirty years evolution of urban growth, transport demand and supply, energy consumption, greenhouse and pollutants emissions in Greater Cairo Study, research in transport economic magazine, https://www.researchgate.net.

DRTPC, (2009): Urban Mobility in Greater Cairo; Trends and Prospects Research Study, Cairo University, WWW.planbleu.org/en

EBRD,( 2014): Environmental and Social Impact Assessment - Vol.1 NonTechnical Summary; Additional service for Cairo Metro Line 3 Phase 3, www.ebrd.com

EEAA, (2010): Egypt Second National Communication Report, www.eeaa.gov.eg

EEAA, (2012): Estimated GHG Inventory in Egypt Report, www.eeaa.gov.eg

EEAA,(2012): Environmental and Social Impact Assessment Study, www.eeaa.gov.eg

EIA, (2010): Country Analysis Brief Egypt Report, https://www.eia.gov

GIZ, (2010/2011): International Fuel Prices Report, https://www.giz.de

Hassan A. H. Mahdy, (2012): Towards Reliable Public Bus Services in Greater Cairo Study, https://www.sign-ific-ance.co.uk

International Energy Association- IEA, (2012): CO2 Emissions from Fuel Combustion Report, https://www.iea.org 
Japan International Cooperation Agency-JICA,(2008): Strategic Urban Development Master Plan Final Report, https://www.jica.go.jp/english

Khalid A. Abbas, (2012): Urban Transport in Egypt, Greater Cairo Study, www.euromedtransport.org

Ministry of Finance-MOF, (2009): Framework Environmental and Social Assessment (FESA) for Egypt Vehicle Scrapping and Recycling Program. www.mof.gov.eg/MOFGallerySource/English

United Nation Development Program-UNDP,(2013): Egypt Sustainable Transport Project

Document, https://erc.undp.org/evaluation/documents

World Bank and International Finance Corporation, (2007): Preparation Missions for greater Cairo Development (Project Document), WWW.worldbank.org

World Bank,( 2006): Greater Cairo: A Proposed Urban Transport Strategy (Project Document), https://openknowledge.worldbank.org

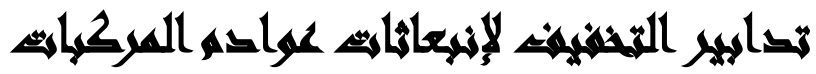

\section{[r]}

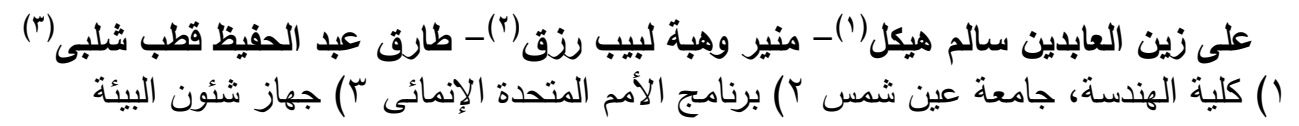

\section{(المستخلص}

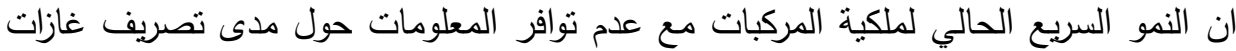

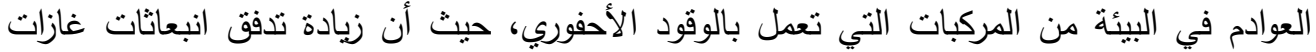

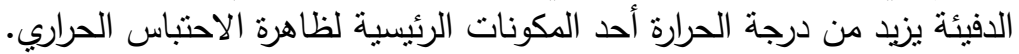

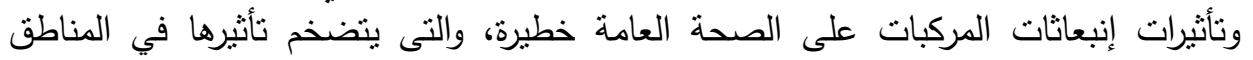

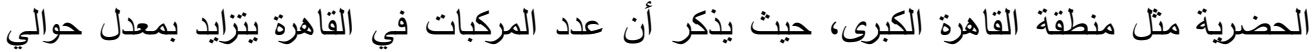
P. .

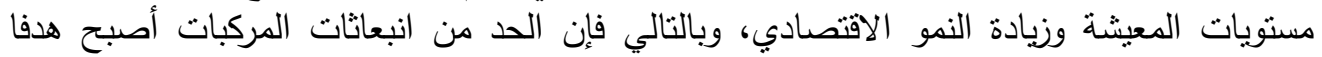
رئيسيا من أنثطة الإدارة البيئية في مصر. 
J. Environ. Sci.

Institute of Environmental Studies and Research - Ain Shams University

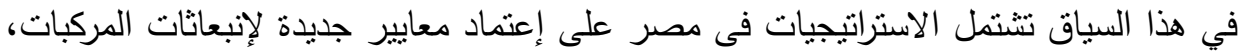

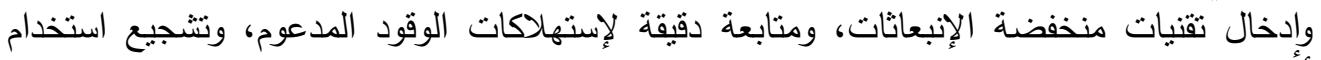
أنواع بديلة من الوقود النظيف. 